\title{
STIGLER'S INFLUENTIAL CONTRIBUTION TO ECONOMIC THOUGHT
}

\author{
Artidiatun Adji \\ Faculty of Economics and Business, Universitas Gadjah Mada, Indonesia \\ (arti.adji@ugm.ac.id)
}

\begin{abstract}
This paper analyzes George J. Stigler's influential contributions to economic ideas, specifically on industrial structures, the functioning of markets, the causes and effects of public regulation, the economics of information, and on the development of economic thought. Stigler's most influential contribution to economic thought came in his work on information theory. Treating information as a valuable commodity, he explained why prices differ for identical goods. From his work, many other theories have been built to explain economic behavior. A considerable number of works on decision making under uncertainty could not have progressed without an understanding of the role of information. His swing of the pendulum in economic regulation constitutes a great turnabout. He started research, known as public choice, which assumes that government policy makers are driven by self-interest rather than pure concern for the public's welfare. His views have now become those of the mainstream.
\end{abstract}

Keywords: industrial structures, functioning of market, public regulation, economics of information, economic thought, Stigler's contribution

JEL Classification: B29, B30, B31

\section{INTRODUCTION}

George Joseph Stigler won the Nobel Prize in Economic Sciences in 1982 for his seminal studies of industrial structures, the functioning of markets, and the causes and effects of public regulation. The objective of this paper is to describe Stigler's influential contributions to economic thought. This paper is organized as follows: Section 2 will discuss Stigler's work on industrial structures. Section 3 will explore Stigler's contributions to the functioning of markets. Section 4 will discuss his swing of the pendulum on the causes and effects of public regulation, which is considered as a great turnabout. Section 5 will present his other pathbreaking ideas on the economics of information and the development of economic thought, and Section 6 will conclude the paper.

Stigler was born in Seattle, Washington in 1911. He attended various schools in Seattle and went to the University of Washington, where he earned a Bachelor of Arts degree in 1931. He got his graduate degree from the University of
Chicago in 1938. He began teaching in 1936. In 1938, he went to the University of Minnesota, from which he took a leave of absence for several years during the war, as a member of the Statistical Research Group at Columbia University. After the war, he returned to Minnesota, and then moved to Brown University. He taught at Columbia University from 1947 to 1958. In 1958, he accepted an offer from the University of Chicago, where he stayed until his death in 1991. Stigler's PhD dissertation was a historical survey of neoclassical theories. The dissertation was published as Production and Distribution Theories (1941). In the 1940s, he began empirical work on the price theory, starting with a test of the kinked oligopoly demand curve theory of rigid prices. In 1946, he published an early work on linear programming, The Cost of Subsistence. In the 1950s, he proposed the survivor method of determining the most efficient size for enterprises, and worked on delivered price systems and vertical integration, among others. Even prior to his Chicago academic life, he was 
interested in the existence of the dispersion of prices under conditions which economic theory said would yield a single price. That interest culminated in his article The Economics of Information (1961). A steady flow of perceptive and thoughtful articles were collected in Essays in the History of Economics (1965). He always maintained his interest in the history of economics. His autobiography, Memoirs of an Unregulated Economist (1985), challenges and induces his non-economist readers to think as economists do about a variety of problems involving decisions based on limited resources, and provides his economist readers with an insider's view of the development of economic thought from the beginning of his career through his association with the Chicago School. Friedman's opinion on Stigler's memoirs is that they represent his own engaging personality and his extraordinarily various contributions to economics (Friedman, 1999; Stigler, 1982b).

\section{ON INDUSTRIAL STRUCTURES}

Stigler's main contribution to the field of industrial organization, both in the book The Organization of Industry (1968) and in articles after the publication of the book, was the use of empirical evidence to test hypotheses designed to explain features of industrial organization. Industrial economists in that era focused their research on theoretical work. His articles combined subtle theoretical analysis with substantial empirical evidence. These articles illustrated the swing in Stigler's views on antitrust: From being a proponent of antitrust policies to skepticism about even a minimalist policy (Friedman, 1999).

Stigler stated that the purely economic argument against monopoly is very different from what non-economists might expect. Successful monopolists earn extra-large profits by raising prices above what they would be with competition, so that customers pay extra and the monopolists gain. However, economists see no reason to criticize monopolies simply because they transfer any surplus from customers to the monopolists, since economists have no way of knowing who is the more worthy-producer or consumer. The purely economic case against monopoly is that it reduces aggregate economic welfare. When the monopolist raises prices above the competitive level, in order to reap the monopoly profits, customers buy less of the product, so less is produced, and society as a whole is worse-off. A monopoly creates deadweight losses. Diverting from his initial position on antitrust policies, Stigler lost his enthusiasm for them. He argued that several kinds of evidence suggested that monopolies and smallnumber oligopolies have limited powers to earn much more than competitive rates of return on capital. A large number of studies have compared the rate of return on investment with the degree to which industries are concentrated. Less than 25 percent of the variations in profit rates across industries were contributed by concentration (Stigler, www.econlib.org/ library/Enc/Monopoly.html, accessed July 22, 2003).

In The Economists and the Problem of Monopoly (1982), Stigler reviews the attitudes of economists toward monopolies as being a problem with public policy from the era of Smith, Ricardo, Mill, and Marshall, to the Sherman Act. He concludes his survey by stating that the attitude of economists toward a monopoly policy is strongly influenced by the technical price theory (Stigler, 1982: 9). Stigler's article, Notes on the Theory of Duopoly (1940) reappraises certain theories on duopoly which have already been advanced:

"The very magnitude of the literature on the theory of duopoly may be interpreted as indirect evidence of the unsatisfactory state of this theory. Duopoly seems to present one of those problems concerning which, everything sensible that can be said doubtless already has been said, and yet no single solution commands general agreement" (Stigler, 1940: 521).

The theory of duopoly may be summarized when the products are homogeneous and their price and output are the only variables of the policy. The usual solution will be an agreement on price, although not necessarily at the monopoly level, and each duopoly will form 
anticipations with respect to their rival's behavior. Stigler extended the theory of duopoly by including variables of market policy other than price and output, i.e. product differentiation, advertising, research and development, and product variation (Stigler, 1940: 533-539). With differentiated products, the possibility of price competition becomes slightly more realistic, since a duopoly may believe that its price cuts will be ignored, or at most only partially matched by the rival and perhaps only after a time lag. There is no longer any necessity for price uniformity. In the presence of uncertainty, duopolists will engage in many forms of rivalry. Such rivalries have frequently been pointed out in advertising, and the evidence is also clear from research into product improvements, cost reductions, and the expansion of investment. In the case of a product variation, if the variation of the product is profitable, it will be a continuous characteristic of the market. The n-dimensional nature of commodities will increase the number of duopoly relationships, i.e. even if there are many firms making a commodity, usually only relatively few of these firms will be emphasizing the same qualities of product and appealing to the same consumer groups (Stigler, 1940: 541).

Stigler's article titled, A Theory of Oligopoly (1964), accepts the hypothesis that oligopolists wish to collude to maximize joint profits. However, his paper seeks to reconcile this wish with facts, such as that collusion is impossible for many firms, and collusion is much more effective in some circumstances than in others. His empirical evidence shows that the more concentrated the industry structure is, the larger are the price reductions. There are various bits of evidence which are fairly favorable to the theory, but they do not constitute strong support (Stigler, 1964: 44). He concluded by stating:

"More powerful tests will be feasible when the electrical equipment triple-damage suits are tried. The great merit of our theory, in fact, is that it has numerous testable hypotheses, unlike the immortal theories that have been traditional in this area (Stigler, 1964: 59).
The fundamental proposition in the industrial prices literature is that prices in industrial markets, especially those which are oligopolistic in structure, are unresponsive to changes in general business conditions, and this behavior is pervasive. Stigler co-authored an important empirical study of prices with Kindahl, The Behavior of Industrial Prices (1970), which examines the question of price stability and presents meticulous data. The book's statistical evidence helps undermine the long-standing economic maxim that a major segment of the economy sets prices by management decision, rather than in reaction to market factors. Stigler's article (co-authored with Kindahl), Industrial Prices, as Administered by Dr. Means (1973) aimed at examining the evidence on the view that industrial prices are rigid to change. Means (1972) has reinterpreted the evidence on pricing behavior presented in Stigler's and Kindahl's book. Further, Stigler wrote that Means is duly rewarded for his diligence by finding that the administered-price thesis is fully confirmed (Stigler and Kindahl, 1973: 717).

Means' initial interpretation of an administered price is a price which is set by administrative action and held constant for a period of time. Means' new reinterpretation was that administered prices should be corrected for trends, and that the administered price thesis is not concerned with regular seasonal price jumps. The administered price thesis holds that a large body of industrial prices do not behave in the fashion that classical theory would lead one to expect. Stigler stated that Means' theory has become difficult to refute or confirm, due to the absence of a well-defined set of criteria, which means no test can be convincing. The thesis that modern economics has received from Means is that perverse or unresponsive price behavior is widespread. Stigler's and Kindahl's study contradicts that thesis (Stigler and Kindahl, 1973: 717-718; 721). Now, Stigler's view on this matter has become the mainstream view.

\section{ON FUNCTIONING OF MARKETS}

Stigler's significant contribution to modern ways of thinking about economics lay in the intellec- 
tual development of the production theory in his book Production and Distribution Theories, the Formative Period (1941) and his subsequent article on the development of the utility theory (1950). They were very influential in forming modern economics' consensus on topics that are central to the discipline, and remain as the standard references (Rosen, 1993: 812).

Stigler's first important publication after his dissertation was a textbook, The Theory of Competitive Price (1942) which was followed by revised version titled The Theory of Price (1946). His textbook was the first modern text about microeconomic theory, and it provided the style and organization for subsequent microeconomic theory textbooks to mimick (Rosen, 1993). In this book, he illustrated many principles of economics with real data, rather than hypothetical examples. Its systematic linking of a highly abstract theory to observable phenomena is unique among intermediate textbooks on price theory, as is its concise yet rigorous exposition. Stigler deserves credit for getting economists to look at data and evidence. His knowledge of where economics came from allowed him to contemplate large-scale problems in the natural course of things. However, he was interested in both large and small problems (Friedman, 1999; Rosen, 1993: 812). In his paper Production and Distribution in the Short Run (1939), Stigler argued how a more flexible organization of production would better accommodate variations in output, and why this refinement of the standard model was needed to account for the empirical time series insensitivity of average production costs. The idea is an important generalization of the Marshallian distinction between the short run and long run, and a clear precursor to the modern literature on the adjustment of quasi fixed factors over business cycles (Rosen, 1993: 812-813).

A famous theorem in economics states that a competitive enterprise economy will produce the largest possible income from a given stock of resources. No real economy meets the exact conditions of the theorem, and all real economies will fall short of the ideal economy. The divergence of the real economies from the ideal ones is called market failure. In Stigler's view, however, the degree of market failure for the US economy is much smaller than the political failure caused by the imperfections in economic policies found in real political systems. The merits of laissez faire rest less upon its famous theoretical foundations than upon its advantages over the actual performance of rival forms of economic organization (Stigler in www.econlib.org/librari/Enc/Monopoly.html).

In Smith's Travels on the Ship of State (1971), Stigler argued that Smith gave selfinterest pride of place in analyzing the economic market, but he did not give it the same role in analyzing the political market. Smith's failure to do so constitutes Stigler's main and only criticism of the Wealth of Nations, that "stupendous palace erected upon the granite of self-interest" (Friedman, 1999). Stigler mentioned that his work on search and information stemmed from the classical debates on the limits of defining markets in terms of price uniformity. The hints for the following question, "How much price dispersion could a single market sustain?" are in the article that tracked the late development of the concept of perfect competition titled, Perfect Competition, Historically Contemplated (1957). Stigler's fundamental thesis is that hardly any important improvement in general economic theory can fail to affect the concept of competition. He argued that the concept has proved to be a tough and resilient concept and it will stay within the existing literature on economics for a long time (Stigler, 1957: 17).

\section{ON CAUSES AND EFFECTS OF PUBLIC REGULATION: A GREAT TURNABOUT}

The absence of quantitative studies of the actual effect of regulation challenged Stigler. In 1962 he wrote articles with Claire Friedland on the regulation of the prices of public utilities, What Can Regulators Regulate? The Case of Electricity. The article concluded that the regulation of electric utilities had produced no significant effect on the rates they charged. This was followed two years later by Public Regulation of the Securities Market (1964). The 
article investigated the adequacy of the controls the Securities and Exchange Commission (SEC) exercise over the security markets. This article concluded that purchasers of new stock issues fared no better or worse after the creation of the SEC than before (Friedman, 1999, and Stigler (1964: 117-142). In the Theory of Economic Regulation (1971), Stigler answered the question of "If regulation does not generally achieve its stated objectives, why have so many agencies been established and kept in existence?" Stigler's answer was "As a rule, regulation is acquired by the industry and is designed and operated primarily for its benefit". Further, Stigler argued that two alternative views of the regulation industry were held: (i) Regulation is instituted primarily for the protection and benefit of the public at large, or some large subdivision of the public, (ii) the political process defies rational explanation. His thesis has become the orthodox view in the profession: The idealistic view of public regulation is deeply imbedded in professional economic thought. The fundamental vice of such a view is that it misdirects attention -to preaching to the regulators rather than changing their incentives. His analysis fed the field of public choice by shifting it from viewing the political market as not being susceptible to economic analysis - one in which disinterested politicians and bureaucrats pursue the public interest - to viewing it as one in which the participants are seeking, as in the economic market, to pursue their own interests, and hence are subject to analysis with the usual tools of economics (Friedman, 1999). Stigler argued that governments do not end up creating monopolies in industries by accident. Rather, they regulate at the command of producers who capture the regulatory agency and use regulation to prevent competition. Probably of more importance than the evidence itself was the fact that Stigler made this viewpoint respectable in the economics profession. It has now become the mainstream view.

Stigler shifted his views on antitrust laws. He was a proponent of antitrust laws in the 1940s and 1950s. He was influenced by his colleague and friend, Henry Simon from the University of
Chicago. Following Simon, who proposed the nationalization of uncompetitive industries such as railroads and utilities, Stigler proposed the fragmentation of concentrated big businesses and punishments for companies engaged in collusion. He provided testimony in Congress in 1950 and advocated that the US Steel Corporation be broken up. By the early 1970s, Stigler had shifted his view and was influenced by the work of Aaron Director and Joseph Schumpeter and a new theory of oligopoly. He concluded that concentration did not necessarily cause a monopolistic pricing. Stigler opposed most antirust legislation. He had admitted his mistakes and changed his views. It takes courage and honesty to go against one's vested interests, especially after publishing books and articles on his previous way of thinking about antitrust laws. It is an admirable thing from an academia who was willing to alter his view when he was convinced by the facts or a new theory. Therefore, Stigler's change of view can be regarded as one of great turnabouts in economic thought

(www.libertyhaven.com/theoreticalorphilosophi cal issues/austrianeconomics, accessed July 22, 2003).

In his Nobel Memorial Lecture, Stigler stated that there is an interesting asymmetry in the success of the literature on economic regulation, when it deals with the two problems into which the theory is commonly divided: (i) Why are regulatory policies adopted and abandoned? (ii) What are the effects of regulation? Economists have been much more successful in measuring the effects of policies than in explaining their implementation, since one can choose the effects of a policy to study, and usually the more easily measured effects are selected for examination. Studies of the effects of regulatory policies have usually been concerned with their effect upon prices and outputs, although the effects desired by the proponents of these policies have probably been upon income distribution. Specifically, he wrote:

"The panoply of regulatory measures can be used to affect vast income redistributions, and these redistributions of income do not 
appear explicitly in the budget of the state. The frequent exclusion of new entrants from a field, for example, leads to smaller outputs, higher prices, and higher profits for the protected enterprises, and allows these benefits to increase with the growth of the protected are. If these income transfers are as large as fragmentary evidence suggests, the theory of regulation may well become a full partner of tax and expenditure theory in public finance" (Stigler, 1982: 68).

In addition, Stigler's focus on statistical documentation has been revolutionary. Much of the credit for the growing interest in the empirical verification of economic theory therefore must be given to Stigler (Current Contents, 1984).

\section{STIGLER'S PATH BREAKING CONTRIBUTION}

\section{On Economics of Information}

The Economics of Information (1961) gave birth to an essentially new area of study for economists. Stigler termed it as his most important contribution to economic theory. In his article, he stated:

"One should hardly have to tell academicians that information is a valuable resource: Knowledge is power. And yet it occupies a slum dwelling in the town of economics. Mostly it is ignored: The best technology is assumed to be known; the relationship of commodities to consumer preferences is a datum. And one of the informationproducing industries, advertising, is treated with a hostility that economists normally reserve for tariffs or monopolists. ...our understanding of economic life will be incomplete if we do not systematically take account of the cold winds of ignorance" (Stigler, 1961: 213-224).

This article was one of his most cited articles, i.e. 57 citations in 2006 (Diamond, 2006). It discusses the costs and benefits to producers and consumers of supplying and obtaining information about commodities. In his A Theory of Oligopoly (1964), Stigler was the first economist to show how information's acquisition and its statistical inferences would be rationally used by economic agents and would affect their actions. In the article, Stigler introduced aspects of the statistical decision theory into applied economics, and showed by important examples how those ideas could be used in practical cases (Rosen, 1993: 813; Current Contents, 1984). In the article, Stigler stated:

"The present paper accepts the hypothesis that oligopolists wish to collude to maximize joint profits. It seeks to reconcile this wish with facts, such as that collusion is impossible for many firms and collusion is much more effective in some circumstances than in others. The reconciliation is found in the problem of policing a collusive agreement, which proves to be a problem in the theory of information (Stigler, 1964, p.44).

In his Nobel Memorial Lecture, Stigler stated that economists have always known that the extent and accuracy of the knowledge of the economic actor had influence, and often a decisive influence, on his behavior and therefore on the behavior of markets (Stigler, 1982: 65). In his 1961 article, he proposed the use of the standard economic theory of utility-maximizing behavior to determine how much information people would acquire with special attention to the prices at which they would buy and sell, and a year later he made an application of the analysis to labor markets. He was happy to witness the emergence of the Economics of Information:

"The proposal to study the economics of information was promptly and widely accepted, and without even a respectable minimum of controversy. Within a decade and a half, the literature had become so extensive and the theorists working in the field so prominent, that the subject was given a separate classification in the Index of Economic Articles, and more than a hundred articles a year are now devoted to this subject" (Stigler, 1982: 66). 
Stigler's article titled, "Information in the Labor Market" (1962), argued that job seekers needed short periods of unemployment in order to seek higher wages. Stigler's argument is now called the theory of search unemployment (www.econlib.org/library/Enc/bios/Stigler.html, accessed July 22, 2003). Even in industries with a constant prevailing wage, variances in wage rates still exist. Hence, the unemployed are as much information seekers as job seekers:

"No worker, unless his degree of specialization is pathological, will ever be able to become informed on the prospective earnings which would be obtained from every one of these potential employers at any given time, let alone keep this information up to date. He faces the problem of how to acquire information on the wage rates, stability of employment, conditions of employment, and other determinants of job choice, and how to keep this information current" (Stigler, 1962: 94).

\section{On Development of Economic Thought}

Stigler is also highly regarded as an economic historian. He wrote numerous articles on the history of ideas. $\mathrm{He}$ has assembled an extraordinary library of the classics. His interests in, and commitment to, the history of thought had personal consumption and investment aspects which creates benefits for the economics community. Stigler invested heavily in the classics since he found them fertile grounds for gaining deep economic understanding and insight. Stigler added important, original, and thoroughly modern ideas to the classics when he took inspiration from them. He added empirical orientation and commitment to quantitative evidence which were not derived from earlier economists (Rosen, 1993: 810-812).

Stigler's article, The Development of Utility Theory (1950) was written with the aim of simply setting forth the major steps in the development of a branch of economic theory, hoping that it can be justified by its contribution to the understanding of modern economics, and also to answer the question, "Why do economists change their theories?" The article covers the period from Smith (1776), Bentham (1789), Dumont (1802), Ricardo, Dupuit (1844), Gossen (1854), Jevons, Menger, and Walras (1870s), Marshall, to Slutsky (1915). There is a sluggishness in the way the utility theory progressed. The additive utility function was popularized in the 1870s and it was 1909 before the implication of positively sloping income curves was derived. The generalized utility function was proposed in 1881 and in 1915 the implications were derived. The chief of these implications is that if consumers do not buy less of a commodity when their incomes rise, they will surely buy less when the price of the commodity rises. This was the chief product. These very able economists had known all along that demand curves have negative slopes, quite independently of their utility theorizing. Stigler stated that the above mentioned economists improved economics substantially:

"Had specific tests have been made of the implications of theories, the unfruitfulness of the ruling utility theory as a source of hypotheses in demand would soon have become apparent. Had these economists sought to establish true economic theories of economic behavior -that is, to isolate uniformities of economic events that permitted prediction of the effects of given conditions -they would not long have been content with the knowledge that demand curves have negative slopes.... That such able economists were delayed and distracted by the lack of a criterion of refutable implications of theories would be a finding as useful to us as any of the fine theoretical advances they made" (Stigler, 1950: 396).

Stigler helped keep alive one of Smith's great unworked themes in his article title, "The Division of Labor is Limited by the Extent of the Market" (1951). In describing the evolution of industry, he argued that increasing return activities would be vertically integrated within firms when an industry was young and newly developed. As the industry grew and demand increased sufficiently, they would be spun off into independent units. This picture of vertical disintegration with progress better describes 
changes in the organization of knowledge over time, than in many material goods industries (Rosen, 1993: 813-814).

Stigler analyzed the work of Smith in The Successes and Failures of Professor Smith (1976). He argued that Smith had one overwhelming and proper success-the theorem on resource allocation under competition - and several minor successes. He further argued that Smith's most important analytical failure was the hierarchy of employments of capital. Smith's hierarchy of employments of capital never had a prospect of scientific prosperity due to logical error (Stigler, 1976:1199-1211). Stigler appraised Smith as successful in providing a theorem of almost unlimited power on the behavior of man. In Stigler's words, Smith's construct of the self-interest-seeking individual in a competitive environment is Newtonian in its universality (Stigler, 1976: 1212).

Stigler wrote several articles on Ricardo. In Sraffa's Ricardo (1953), he argued that Ricardo was a fortunate man, who lived in a period when an untutored genius could still remake economic science, and lived in a nation where two great problems, i.e. inflation and free trade, gave direction and significance to economics. $\mathrm{He}$ argued that Ricardo's policy recommendations were profoundly good but his theory was not of the highest quality (Stigler, 1953: 686). In Ricardo and the 93\% Labor Theory of Value (1958), Stigler seeks to set forth precisely what Ricardo's theory of value was, and to examine the interpretation placed upon it by his leading contemporaries. He concluded that Ricardo's theory is relatively more misunderstood today than it was in his lifetime, and that one can build a strong case that the modern economist need not be acquainted with Ricardo's work, but there is no case for his being acquainted with an imposer (Stigler, 1958: 358-367). In The Ricardian Theory of Value and Distribution (1952), Stigler stated that economics is the body of substantive generalizations on the workings of economic systems, and Ricardo did not enlarge this body of knowledge by much. Ricardo's one addition to Smith's work was the systematic, though only partial, recognition of diminishing returns. Ricardo had great powers of abstraction and synthesis. Population, natural resources, capital accumulation, and the distribution of income were woven into a sweeping theoretical system (Stigler, 1952: 206). Stigler compared the work of Smith and Ricardo:

"Although Smith and Ricardo had cost theories of value, there were important differences in the basic principles: (i) Smith believed that population changes lagged behind changes in the quantity of capital; therefore, wages were indefinitely above the subsistence level in an advancing society, (ii) The tenor of Smith's theory of rent, which was not given a coherent statement, was that aggregate rents are a residual but that the rent of any one use of land is a cost determined by the alternative uses of the land. Ricardo ignored the multiplicity of uses of land; (iii) Smith believed that the accumulation of capital led to a fall in the rate of profits, whereas Ricardo -arguing from Say's law- denied that capital accumulation had any effect upon the rate of profits (unless the cost of food increased); (iv) Smith's measure of value was designed to answer the same question as modern index numbers: How to eliminate differences in the value of money and thus ascertain the real changes. Ricardo's measure, on the other hand, was not a price deflator. It was designed to locate the source of changes in value in order to connect wages and profits to labor's and capital's share in the national income minus rents. Modern economics is closer to Smith's position than to Ricardo's on each of these differences, although in the case of rent we use Ricardo's techniques to analyze Smith's problem. Ricardo had neither Smith's genius for isolating fundamental empirical relationships, nor his supreme common sense. Yet, Ricardo was, in his own terrain of technical analysis, superior to Smith. Measured by the significance of the variables and the manageability of the system, he fashioned what is probably the most impressive of all models 
in economic analysis" (Stigler, 1952: 204207).

Stigler's many contributions to economic theory were all a by-product of seeking to understand the real world, and nearly all led to an attempt to provide some quantitative evidence to test the theory, or to provide empirical counterparts to theoretical concepts (Friedman, 1999). De Gustibus Non Est Disputandum (1977)-translated roughly as There Is No Accounting for Taste which was written together with Gary S. Becker, Nobel Prize winner in Economics in 1992, is probably the best example of Stigler's combination of theory and confirmation by observational data. In that article, it is stated that according to the belief among traditional economists, certain economic phenomena stem from personal taste and are therefore unsuitable for scientific analysis. However, in the paper, Stigler rejects the traditional view and proposes that standard economic logic and analysis be applied as extensively as possible. He asserts that it is not tastes that change, but levels of economic information. Stigler's conclusions yield useful predictions about behavior (Stigler and Becker, 1977: 76-90). In his Nobel Memorial Lecture in 1982, The Process and Progress of Economics, Stigler mentioned again the idea of this article, by writing that Gary Becker has suggested that a substantial resistance to the acceptance of new ideas by scientists can be explained by the concept of specific human capital and the concept of risk aversion. The concept of specific human capital suggests that an established scholar possesses a valuable capital asset in his command of a particular body of knowledge, and that capital would be reduced if his knowledge were made obsolete by the general acceptance of a new theory. The risk aversion concept leads young scholars to prefer mastery of the established theories, rather than seeking radically different theories (Stigler, 1982a: 65; Stigler, 1982b). Stigler also presented the history of economics in his Nobel Memorial Lecture. $\mathrm{He}$ began by distinguishing the pre-scientific stage, i.e. the mercantilism, from its scientific stage. The mercantilism is characterized by the incompleteness of the body of knowledge, and by the absence of a set of interacting practitioners who are devoting a large part of their lives to the accumulation of knowledge. Then he distinguished the economic science as the environmental view. The environmental view presents a systematic history of economic thought in terms of the responses of each generation to its environment. The responsiveness of economics to environmental problems will be more complete and more prompt, the more urgent the problems of the day are (Stigler, 1982a: 57-61; Stigler, 1982b).

\section{CONCLUDING REMARKS}

Stigler's tangible work on industrial structures, the functioning of markets and the causes and effects of public regulation gained him the Nobel Prize in Economics. Yet, his intangible contributions to economics were also as important. $\mathrm{He}$ has increased the standards of industrial economics far beyond the earlier periods. He has also made valuable contributions to the history and sociology of economic thought.

Stigler's most influential contribution to economic thought was his work on information theory. Reconciling the theory with the facts, Stigler investigated the importance of information. He explained why prices differ for identical goods. From his work, many other theories are built to explain economic behavior. Studies on decision making under uncertainty would not have not have progressed without an understanding of the role of information, as put by Stigler.

Stigler's journey to the development of economic thought goes beyond the traditional issues of monopoly, regulation, and information. His swing of the pendulum in economic regulation constitutes a great turnabout. He was also the one who started the public choice study, which assumes that government's policy making is driven by self-interest rather than a pure concern for the public's welfare. His view has become the mainstream. Stigler's vision on economic thought was path-breaking, serving economic literature extraordinarily well. 


\section{REFERENCES}

Current Contents, 1984. "Current Comments: Essays of An Information Scientist", 15: 3-7

Diamond, Jr., A., 2006. "Measurement, Incentives, and Constraints in Stigler's Economics of Science", The European Journal of the History of Economic Thought, 13, no. 1.

Friedman, M., 1999. "George Joseph Stigler: A Biographical Memoir", National Academy of Sciences, National Academies Press, Washington, DC.

Means, G., 1972. "The Administered-Price Thesis Reconfirmed". The American Economic Review, 62, 292-306.

Rosen, S., 1993. "George J. Stigler and the Industrial Organization of Economic Thought". The Journal of Political Economy, 101, (5), 809-817.

Stigler, G. J., 1939. "Production and Distribution in the Short Run". The Journal of Political Economy, 47, (3), 305-327.

Stigler, G. J., 1940. "Notes on the Theory of Duopoly". The Journal of Political Economy, 48, (4), 521-542.

Stigler, G. J., 1941. Production and Distribution Theories, the Formative Period. New York, Macmillan.

Stigler, G. J., 1942. The Theory of Competitive Price. New York and London, MacMillan.

Stigler, G. J., 1946. The Theory of Price. New York and London, MacMillan.

Stigler, G. J., 1950. "The Development of Utility Theory. I", The Journal of Political Economy, 58, (4), 307-327.

Stigler, G., J., 1950. "The Development of Utility Theory. II", The Journal of Political Economy, 58, (5), 373-396.

Stigler, G. J., 1951. "The Division of Labour is Limited by the Extent of the Market", The Journal of Political Economy, 59, (3), 185193.

Stigler, G. J., 1952. "The Ricardian Theory of Value and Distribution", The Journal of Political Economy, 60, (3), 187-207.

Stigler, G. J., 1953. "Sraffa's Ricardo", The American Economic Review, 43, (4), 586509.
Stigler, G. J., 1957. "Perfect Competition, Historically Contemplated", The Journal of Political Economy, 65, (1),.1-17.

Stigler, G. J., 1958. "Ricardo and the 93\% Labor Theory of Value", The American Economic Review, 48, (3), 357-367.

Stigler, G. J., 1961. "The Economics of Information", The Journal of Political Economy, 69, (3), 213-225.

Stigler, G. J., 1962. "Information in the Labor Market", The Journal of Political Economy, Vol. 70, (5), Part 2: Investment in Human Beings, 94-105.

Stigler, G. J and C. Friedland, 1962. "What Can Regulators Regulate? The Case of Electricity", The Journal of Law and Economics, 5, 1-16.

Stigler, G. J., 1964. "A Theory of Oligopoly", The Journal of Political Economy, 72, (1), 44-61.

Stigler, G. J., 1964. "Public Regulation of the Securities Markets", The Journal of Business, 37, (2), 117-142.

Stigler, G. J, 1965. Essays in the History of Economics. Chicago, The University of Chicago Press.

Stigler, G. J., 1968. The Organization of Industry, Homewood, Ill, Richard D. Irwin, Inc.

Stigler, G. J., and J. K. Kindahl, 1970. The Behavior of Industrial Prices, Columbia University Press.

Stigler, G.J., 1971. "Smith's Travels on the Ship of State", History of Political Economy, 3 (2), 265-277

Stigler, G. J., and J. K. Kindahl, 1973. "Industrial Prices, as Administered by Dr. Means", The American Economic Review, 63, (4), 717-721.

Stigler, G. J., 1976. "The Successes and Failures of Professor Smith", The Journal of Political Economy, 84, (6), 1199-1213.

Stigler, G. J., and G. S. Becker, 1977. "De Gustibus Non Est Disputandum", The American Economic Review, 67, (2), 76-90.

Stigler, G. J., 1982. "The Process and Progress of Economics", Nobel Memorial Lecture, Economic Sciences, 57-76. 
Stigler, G. J., 1982. “Autobiography”. Available at www.nobel.se/economics/laurates/1982/stig ler-bio.html, accessed July 22, 2003.

Stigler, G. J., 1985. Memoirs of an Unregulated Economist. Chicago, University of Chicago Press.

Stigler, G. J., "Monopoly", 1-6. The Concise Encyclopedia of Economics. Available at
www.econlib.org/library/Enc/Monopoly.ht ml, accessed July 22, 2003.

The Concise Encyclopedia of Economics. "Biography of George J. Stigler (19111991)", 1-4. Available at www.econlib.org/library/Enc/bios/Stigler.ht ml, accessed August 10, 2017.

Notice: The Journal of Indonesian Economy and Business including the Editors decline all errors and flaws found in this article. Authors are fully responsible for them. 